\title{
WALT WHITMAN ON BROTHER GEORGE AND HIS FIFTY-FIRST NEWYORK VOLUNTEERS: AN UNCOLLECTED NEW YORK TIMES ARTICLE
}

\author{
Martin G. Murray
}

WALT WHITMAN's CIVIL WAR journalism falls neatly into two categories: brother George, and everything else. While the latter category encompasses a potpourri of topics, from hospital visits to Lincoln's inauguration to the weather in Washington, D.C., the former category focuses tightly on the military valor of George Washington Whitman and his Fifty-first New York Volunteers. To date, scholars have collected five such newspaper articles pertaining to George's regiment, beginning with the January 5, 1863, Brooklyn Daily Eagle, and ending with the August 5, 1865, Brooklyn Daily Union. ${ }^{1}$ To these can be added a sixth, unsigned article published on January 24, 1865, in the New York Times. A transcription of the article follows, along with supporting documentation of Whitman's authorship.

\section{The Fifty-first New-York Volunteers.}

Since the capture of this veteran regiment last September at the battle of Poplar Grove Church, below Petersburgh, the friends of the officers and men had lost all trace of them-no letters being received, and much anxiety beginning to be felt about them. But within the current week an exchanged Union Chaplain, Rev. Mr. EMERSON, returned from confinement at Danville, Va., brings word of the Fifty-first officers at the latter place. Maj. WRIGHT, Capt. G. W. WHITMAN, Lieuts. POOLEY and ATKINSON, and some eight or ten more officers, are there, or, rather, were, toward the last of November. They were kept in a large tobacco warehouse, and were doing as well as men could do under such circumstances. Mr. EMERSON, after leaving Danville to be paroled, was detained over a month in Richmond. $\mathrm{He}$ is now at Annapolis. $\mathrm{He}$ brought a number of those significant slips of paper, of all textures, colors and degrees of legibility, known so well to persons familiar with the Southern prisons and with the returned Union prisoners - deaths, memoranda, messages, \&c. Among these slips is one written by Capt. WHITMAN, of the Fifty-first, dated at Danville, Nov. 23, and simply addressed to his mother in Brooklyn, with the indorsement, "Well and hearty."

In our former sketch of the Fifty-first we should have mentioned a gallant officer, Capt. DANIEL E. JENKINS, shot and instantly killed while leading his men in the hottest of the Wilderness fight last May. We also omitted to mention Lieut.-Col. 
MITCHELL, a valuable officer, who served his three years, and was honorably mustered out. Several company officers and brave soldiers might also have been properly mentioned. Then we are told that the Fifty-first esteems, as part of its regimental history, the making of such militaires as EDWARD FERRERO, now Major-General by brevet, and ROBERT B. POTTER, also Major-General by brevet, both of this city, and who were the two first commissioned Colonels of the Fifty-first; and, as they say, two braver soldiers or better officers, while they were in command of the Fifty-first, no regiment could ever possess, whatever must be said of subsequent matters.

The rank and file of the Fifty-first, consisting of some 350 men, captured at Poplar Grove Church, we have no intelligence of. They are distributed somewhere in the Southern prisons. The remnant, some 50 to 60 men, are still in their old camp, in the Ninth Corps. Of the rumor that Gov. SEYMOUR, just before he left office, had been induced to appoint a Capt. MCKIBBEN to the Colonelcy of the Fifty-first, thus taking advantage of the absence by captivity of the old officers, we are glad to be able to state it is an error. As indeed no honorable soldier would procure advancement by a trick upon brave men in misfortune, nor accept promotion only belonging to them, promotions that should be waiting for them when they return with their regiment from captivity.

The unsigned article clearly bears Whitman's imprint, as shown by comparison with extant manuscripts and collected journalism. To begin, the opening paragraph corresponds closely to an entry made by Whitman in his journal a few days prior to the article's publication date. As transcribed by Edward Grier, the manuscript reads:

\section{Brooklyn, fan 19 \& 20, 1865}

We have just heard from George after a blank of four months. He is in the Confederate Military Prison at Danville, Va., (or rather was on Nov 27, for his letter has been nearly two months getting here.) When captured, he $\&$ the other officers were taken to Libby Prison in Richmond, from there to Salisbury, N.C. \& from there to Danville, where they are kept (on corn meal, a little bacon, \&c.) in a tobacco warehouse. There are 350 officers in confinement. Every thing is very miserable, starvation, rags, \&c.

We first received one of those significant slips of paper (of which I have seen so many bushels one time \& another, brought up by exchanged prisoners, dingy, soiled, halflegible, records of death, home addresses, of prisoners, \&c.) written by his own hand, with mother's name on, \& dated at Danville, Va. November 23d, 1864 and the words, "well \& hearty." This slip came through after long delay by an exchanged chaplain. ${ }^{2}$

But the next day, (Jan 20, '65,) we received through the mail quite a letter, dated November 27, written in good spirits, putting the best face on his imprisonment, \& claiming to be in good health. He mentioned the other officers of the regiment, Major Wright, Lieut Pooley, \&c. The prison is in charge of Lieut. Col. Robert C. Smith, Confederate Army. ${ }^{3}$

The opening paragraph of the Times article also corresponds closely to parts of a January 19, 1865, Brooklyn Daily Union article attributed to Whitman by Jerome Loving:

The friends of Capt. George W. Whitman, of this city, captured last September in battle near Petersburgh, Va., will be glad to learn that he has just been heard from, though for the first time since his capture. 
On September $30^{\text {th }}$, at the battle of Poplar Grove Church, Capt. Whitman was among those cut off on the extreme left at nightfall and captured. . . . Since then his relatives here have had no word or knowledge of him until yesterday they received by the hands of an exchanged prisoner a small slip of paper written in pencil by Capt. Whitman's hand stating that he was at Danville, Va., and doing well. The slip is dated November $23,1864 .{ }^{4}$

Furthermore, the second paragraph of the January 1865 Times article declares itself a sequel; its apparent predecessor is an October 29, 1864, Times article attributed to Whitman by Emory Holloway. ${ }^{5}$ With a very similar title of "Fifty-first New-York City Veterans," the October 1864 piece recounts in considerable detail the exploits of George Whitman's regiment, from its first muster in October 1861, through its capture virtually en-masse at Poplar Grove Church, Virginia, in September 1864. Significantly, the galleys for this October 1864 article, in the collection of Yale University's Beinecke Library, contain substantial marginalia in Whitman's hand which seemingly were intended for use in a follow-up article. Most did not find their way into the subsequent January 1865 Times piece. However, one notation-"Capt. D. E. Jenkins ... killed in the Wilderness Campaign" - apparently was the genesis for the opening sentence in the second paragraph, which states, "In our former sketch of the Fifty-first we should have mentioned a gallant officer, Capt. DANIEL E. JENKINS, shot and instantly killed while leading his men in the hottest of the Wilderness fight last May."

The last sentence of paragraph two praises the regiment's first two commanders, Edward Ferrero and Robert Potter, but obliquely criticizes their successor, Colonel Charles W. LeGendre. In his notes of a December 1864, interview with the Fifty-first's Lieutenant Colonel R. Charlton Mitchell, Whitman recorded a far blunter assessment of the Colonel's capabilities: "LeGendre was an incompetent officer in every respect" (NUPM, 2:702). In a xenophobic pique, Whitman had earlier deplored the 1863 appointment of the French-born and educated soldier: "LeGendre is now Col. of the $51^{\text {st }}$-it's a pity if we havn't Americans enough to put over our old war regiments-(I think less and less of foreigners, in this war...)."

Finally, the closing paragraph of the January 24, 1865, Times article corresponds to an additional Whitman manuscript written three days before. As transcribed by Grier, it states:

Fan 21, 1865, New York.

Had an interview to-day with E F Shepard of Wall Street, New York. He told me that Capt McKibbern had been commissioned Colonel of $51^{\text {st }}$ by special application of General Potter. Taking further advantage of the captivity the regular officers, an appointment had also been made of Lieut Colonel of the $51^{\text {st }}$; but the gentleman assigned 
to the latter post, promptly declined, as he considered it unfair to be foisted over the heads of the regular officers, in this manner. The Governor (Seymour,) then made still another appointment of an outsider to the Lieutenant Colonelcy, of the $51^{\text {st }}$, but he also declined, for same reasons.

A remark was made, by a person present at the interview I speak of, that this trick, taking advantage of the misfortune $\&$ absence by accident of war, of the veteran officers of the $51^{\text {st, }}$ to foist outsiders, over their heads, \& prevent the well/earn'd promotion of those in regular line, was a trick worthy of the New York ward politicians \& one which no honorable General officer would ever initiate, nor would any honorable soldier however ambitious, ever accept promotion through its means. ${ }^{8}$

The position of Colonel of the Fifty-first New York Infantry had opened up with the discharge on October 4, 1864, of both Colonel LeGendre and Lt. Colonel Mitchell, the former for disability from wounds received at the battle of the Wilderness, and the latter after completion of his three-years' enlistment. Gilbert H. McKibbin, Assistant Adjutant General with the rank of Captain in the U.S. Volunteers, was commissioned Colonel of the Fifty-first on December 9, 1864. However, McKibbin declined the appointment and was never mustered in. ${ }^{9}$ Similarly, Samuel N. Benjamin was commissioned Lieutenant Colonel on the same day but also was never mustered in. ${ }^{10}$

Whitman obviously learned of McKibbin's refusal to accept leadership of the Fifty-first before he published the Times article, since he corrects the misimpression held by Eliot F. Shepard ${ }^{11}$ and others. But he uses the opportunity to condemn the promotion of outsiders over the heads of the regiment's own leaders, most of whom had, like Whitman's brother George, worked their way up the ranks through meritorious service. Whitman believed strongly in meritocracy as the guiding principle for "a new Army organization fit for America," whose lifeblood was "an exhaustless, intelligent, brave and reliable rank and file." 12 The partisan Whitman placed the blame for the attempted foisting of outsiders on the outgoing Democratic governor of New York, Horatio Seymour, whom Whitman would later damn as "a Copperhead ... of the rankest kind" (Corr., 2: 36). As a leader of the opposition party, Seymour had played the role of bête noir to the saintly (in Whitman's eyes) Abraham Lincoln, opposing the President on emancipation, the draft, and military arrests. ${ }^{13}$ Governor Seymour campaigned actively for Presidential candidate George B. McClellan in 1864 and lost his own bid for re-election when Lincoln's coattails swept Republican Reuben E. Fenton into the governor's mansion in Albany.

As Whitman had urged, promotions did indeed await the captive officers of the Fifty-first New York Infantry. Upon release from Confederate prison, Major John Wright was promoted to Lt. Colonel and Colonel in turn, Captain George Whitman became Major, and First Lieutenants Samuel M. Pooley and William T. Ackerson were made Captain. ${ }^{14}$ By keeping faith with its own "exhaustless, intelligent, brave 
and reliable rank and file," the Fifty-first New York Volunteers had proven itself the exemplar of Whitman's "new Army organization fit for America."

\section{The Washington Friends of Walt Whitman}

\section{NOTES}

1 The three additional articles in the "George" series include an October 29, 1864, New York Times; a January 19, 1865, Brooklyn Daily Union; and a March 16, 1865, Brooklyn Daily Union.

2 The exchanged chaplain was Joseph C. Emerson of the Seventh New Hampshire Infantry. A resident of Fisherville, New Hampshire, Emerson was commissioned Chaplain on October 17, 1861. Captured during the Petersburg campaign at New Market Heights, Virginia, on September 29, 1864, he was imprisoned successively at Salisbury, North Carolina, Danville, Virginia, and Richmond's Libby prison. He was returned on January 14,1865, and mustered out of service on January 20, 1865. (Compiled Military Service Record for foseph C. Emerson, Seventh New Hampshire Infantry, National Archives and Records Administration, Records of the Adjutant General's Office, Record Group 94.)

3 Walt Whitman, Notebooks and Unpublished Prose Manuscripts, ed. Edward Grier (New York: New York University Press, 1984), 2:747-748 (hereafter abbreviated NUPM). I have not included Grier's transcription of Whitman's emendations. The manuscript is at Yale University, Beinecke Library, Walt Whitman Collection, Box 152.

4 Jerome M. Loving, “A Brooklyn Soldier, and a Noble One': A Brooklyn Daily Union Article by Whitman," Walt Whitman Review 20 (March 1974), 27-30.

5 Walt Whitman, The Uncollected Poetry and Prose, ed. Emory Holloway (New York: Peter Smith, 1932), 2:37-41.

6 Yale University, Beinecke Library, Walt Whitman Collection, Box 149. Whitman's marginalia are not included in NUPM.

7 Walt Whitman, The Correspondence, ed. Edwin Haviland Miller (New York: New York University Press, 1961), 1:88 (hereafter abbreviated Corr.).

8 NUPM, 2:706-707. I have not included Grier's transcription of Whitman's emendations. The manuscript is at Yale University, Beinecke Library, Walt Whitman Collection, Box 149.

9 Gilbert H. McKibbin (correct spelling) was not a complete interloper, as he had formerly served with the Fifty-first New York Infantry as Lieutenant from October 9, 1861, through November 12, 1862. He was discharged to accept appointment as Assistant Adjutant-General, U.S. Volunteers. Captain McKibbin was brevetted Major, Lt. Colonel, Colonel, and Brigadier General on December 2, 1864, and was mustered out of the U.S. Volunteers on September 19, 1865. See Frederick Phisterer, New York in the War of the Rebellion, 1861 to 1865 (Albany: J. B. Lyon Company, 1912), 1:407, 3:2408, 5:4294. Curiously, George Whitman described McKibbin in a July 2, 1864, letter to his family as "one of Walt's acquaintances." See George Washington Whitman, Civil War Letters, ed. Jerome M. Loving (Durham, NC: Duke University Press, 1975), 124. 
10 Phisterer, 3:2399, 3:2401.

11 During the Civil War, Elliot F. Shepard served as aide-de-camp on the military staff of New York Governor Edwin D. Morgan, who was also a major-general of volunteers. Shepard was the namesake and former Colonel of the Shepard Rifles, one of three militia units from which the Fifty-first New York Volunteers was formed in 1861. See entry on Shepard in The National Cyclopaedia of American Biography.

12 Walt Whitman, Memoranda During the War (Camden, 1876), 31.

13 See entry on Seymour in Dictionary of American Biography.

14 Phisterer, 3:2395, 3:2400, 3:2410, 3:2413-2414. Whitman misidentified Ackerson as "Atkinson" in the Times article. 